DOI : $10.14746 / p p .2014 .19 .4 .11$

\title{
Cezary TROSIAK
}

Poznań

\author{
Współczesny polski patriotyzm: \\ między wspólnotą narodową a wspólnotą regionalną
}

\begin{abstract}
Streszczenie: W 2014 r. minęła 25. rocznica odzyskania suwerenności politycznej przez Polskę w wyniku upadku komunizmu w Europie. Przy tej okazji prowadzono cały szereg badań, analiz, których celem badawczym było poszukiwanie odpowiedzi na pytanie jak społeczeństwo polskie ocenia mijające ćwierćwiecze. Prezentowany tekst, jest efektem badań, które wpisują się w ten rocznicowy nurt, nad współczesnym rozumieniem patriotyzmu w ogóle, jak i patriotyzmu regionalnego. Badania były prowadzone przez autora jesienią 2013 roku. Materiał empiryczny zebrano za pośrednictwem Internetu, co mocno postawiło problem reprezentatywności uzyskanych rezultatów, jednak z uwagi na liczbę wypowiedzi może być podstawą do sformułowania ogólnych wniosków na temat tego czym jest współczesny patriotyzm dla Polaków. Generalne wnioski są takie, że patriotyzm również się zutylitaryzował, to znaczy Polacy są patriotami wówczas, gdy jest to użyteczne. Jeszcze inny wniosek, jaki można sformułować jest taki, że dla większości badanych patriotyzm regionalny jest komponentem patriotyzmu w ogóle. Wyjątkiem jest Górny Śląsk, gdzie patriotyzm lokalny występuje obok patriotyzmu narodowego, a często i w opozycji go tego drugiego. Jeszcze inny wniosek, jaki nasuwa się w świetle uzyskanych wyników badań jest taki, że patriotyzm zmienia swoje oblicze z martyrologicznego w patriotyzm działań i ich efektów wg zasady ,po czynach ich poznacie”.
\end{abstract}

Słowa kluczowe: patriotyzm, patriotyzm regionalny, regionalizm, tożsamość

\section{Uwagi metodologiczne}

D rezentowany materiał jest zapowiadaną, rozszerzoną wersją raportu z badań, które zostały przeprowadzone przez Wydział Nauk Politycznych i Dziennikarstwa Uniwersytetu im. Adama Mickiewicza w Poznaniu we współpracy z Polską Grupą Wydawniczą Polskapresse Sp. z o.o., jesienią 2013 roku. Sformułowany przez autorów badań problem badawczy brzmiał następująco: Jak współcześnie rozumiany jest patriotyzm? Do czego zobowiązuje przyjęte przez respondentów rozumienie patriotyzmu? Prezentowana wersja raportu rozszerza problem badawczy o formułowanie pytań szczegółowych, czyli, jak rozumiany jest przez badanych patriotyzm lokalny? Jak definiują i oceniają oni swój patriotyzm lokalny? Pierwsza wersja raportu powstała tuż przed świętem listopadowym (Narodowe Święto Niepodległości) prezentowała wyniki, które dotyczyły przede wszystkim tego czym dla współczesnych Polaków w ogóle jest patriotyzm? Jak jest przez nich rozumiane i w czym się przejawia bycie patriotą?

Jedną z konsekwencji przemian zapoczątkowanych rokiem 1989 jest zwrot w kierunku myślenia o patriotyzmie z punktu widzenia również społeczności regionalnych. Przy przyjęciu tej perspektywy zasadnym jest badanie obok patriotyzmu narodowego, patriotyzmu regionalnego i patriotyzmu lokalnego. Perspektywa ta dodatkowo została wzmoc- 
niona faktem, że po piętnastu latach od upadku komunizmu w Polsce, staliśmy się krajem członkowskim Unii Europejskiej. Od połowy lat 80. Unia Europejska przede wszystkim w rozwoju europejskich regionów widzi szansę na skuteczniejszą realizację swoich celów, z których najważniejszym jest zminimalizowanie różnic w dysproporcjach rozwoju poszczególnych części unijnej, regionalnej Europy. Zrównoważenie rozwoju europejskich regionów ma być sposobem na wyeliminowanie źródeł konfliktów, które w XX wieku doprowadziły do wybuchu na kontynencie europejskim dwóch wojen światowych. Dodatkowo zmiana okoliczności, w których przebiega dyskusja na temat patriotyzmu, w tym patriotyzmu regionalnego po roku 1989 w Polsce, ujawniła zasadnicze różnice uwarunkowań regionalnych, które wpływały na jej treści. Warto bowiem zauważyć, że niemal 30\% obszaru III Rzeczpospolitej stanowią ziemie zachodnie i północne, których mieszkańcy w poszukiwaniu punktów odniesienia do dyskusji na temat tożsamości regionalnej byli w zdecydowanie innej sytuacji w stosunku do mieszkańców pozostałych regionów Polski. Istota tej różnicy wynikała z tego, że te drugie były przez cały okres swej historii, częścią kulturowej i politycznej rzeczywistości polskiej, nawet wówczas, gdy w sensie politycznym państwo polskie nie istniało. W przypadku ziem zachodnich i północnych ciagłłósi tej praktycznie w ogóle nie było (vidi Pomorze Zachodnie), bądź zerwana została $\mathrm{w}$ okresie wczesnego średniowiecza, stąd ich mieszkańcy po roku 1989 w pewnym sensie na nowo musieli „konstruować” rzeczywistość społeczną. Proces ten trwa do dnia dzisiejszego co wykazały również nasze badania. Oczywiście niesprawiedliwym byłoby twierdzenie, że w okresie pomiędzy rokiem 1945 a rokiem 1989 nic znaczącego dla „społecznego tworzenia rzeczywistości” (Berger, Luckman, 1983, s. 106), by użyć tego klasycznego sformułowania, nie uczyniono. Istota różnicy pomiędzy tamtym okresem a współczesnością wynika ze zmiany uwarunkowań, w jakich dyskusja ta się toczy. Najważniejsze z nich to uznanie przez zjednoczone państwo niemieckie ostatecznego charakteru polsko-niemieckiej granicy na Odrze i Nysie Łużyckiej oraz uznanie regionalizmu za jeden z kanonów procesu budowania społeczeństwa obywatelskiego. I wreszcie włączenie, przez mieszkańców ziem zachodnich i północnych, do dyskusji nad tożsamością regionalną ziem zachodnich i północnych niemieckich wątków kulturowej i społecznej (uznanie istnienia na tych obszarach mniejszości niemieckiej) przeszłości tych obszarów. Można pokusić się o wniosek, że spełnia się w ten sposób wizja stawania się ojczyzną dla mieszkańców tych ziem zarysowana już w 1946 roku przez St. Ossowskiego, który pisał: „Obszar staje się ojczyzną o tyle tylko o ile istnieje zespół ludzki, który odnosi się doń w pewien sposób i w pewien sposób kształtuje jego obraz. [...] Ojczyzna istnieje tylko w rzeczywistości subiektywnej grup społecznych, które są wyposażone w pewne elementy kulturowe" (Ossowski, 1984, s. 18). W innym swoim tekście Ossowski formułuje wniosek, że między „ojczyzną prywatną” a „ojczyzną ideologiczną” jest miejsce dla ojczyzny regionalnej (Ossowski, 1984, s. 75).

W prezentowanej wersji raportu koncentrujemy się głównie na patriotyzmie regionalnym i jego przejawach. Definiowanie z pozycji zarówno socjologicznych czy politologicznych tego czym jest patriotyzm różni się od potocznego rozumienia tego pojęcia. Termin patriotyzm sprawia wiele trudności tym, którzy ze zdefiniowaniem tego czym jest patriotyzm próbują się zmierzyć. Jest to spowodowane głównie tym, że rozumienie patriotyzmu jest silnie uwikłane w konteksty $\mathrm{w}$ jakich dyskusja na temat patriotyzmu się toczy. Inne będą rozstrzygnięcia tej dyskusji, gdy będzie ona odbywać się w sytuacji za- 
grożenia suwerenności czy niepodległości państwowej czy narodowej, a inne, gdy przebiegać będzie w okresie długotrwałego braku zagrożeń dla tej wolności. Z dużym prawdopodobieństwem można sformułować tezę, że gdyby badania te były prowadzone obecnie, uzyskane wyniki byłyby nieco różne, z uwagi na fakt, że wpływ na nie miałyby wydarzenia, które od kilku tygodni obserwujemy na Ukrainie. Można odnieść wrażenie, że Polacy stanęli, głównie dzięki politykom, którzy wykorzystują wydarzenia na Ukrainie dla celów wewnątrzpolskiej walki politycznej, wobec konieczności udzielenia odpowiedzi na pytanie, które stawało przed wieloma pokoleniami Polaków w przeszłości: jak należałoby zachować się w sytuacji, gdyby doszło do zagrożenia bytu narodowego czy suwerenności państwowej?

Badacze patriotyzmu z problemem dotyczącym operacjonalizacji tego pojęcia spotykają się już na etapie tworzenia narzędzia badawczego. W naukach społecznych jednym ze sposobów rozstrzygania problemu trafności wyników badań, jest porównanie ich z rezultatami uzyskanymi przez innych badaczy. W przypadku naszych badań dokonaliśmy nieco innego zabiegu. Tworząc narzędzie badawcze odwołaliśmy się do ustaleń poczynionych przez autorów badań prowadzonych przez Centrum Badania Opinii Publicznej. Największym dylematem przed jakim stają badacze wykorzystując Internet, aby dotrzeć do respondentów, jest problem reprezentatywności uzyskanych wyników. Ten sposób dotarcia do respondentów radyklanie obniża koszty realizacji badań, lecz odbywa się to kosztem reprezentatywności wyników. Obawialiśmy się, że badana zbiorowość będzie nadreprezentowana $\mathrm{z}$ uwagi na jedne cechy, a niedoreprezentowana $\mathrm{z}$ uwagi na inne. Wątpliwości te dotyczyły głównie cech demograficznych. Dlatego od samego początku należy jasno i wyraźnie stwierdzić, że badana zbiorowość nie jest reprezentatywna dla ogółu mieszkańców Polski, jest to klasyczna próba składająca się z ochotników z wszelkimi mankamentami, jakie ten sposób „doboru” próby generuje. Generalny wniosek, jaki nasuwa się analizując cechy społeczne i demograficzne osób uczestniczących w badaniach jest taki, że ankietę wypełniły osoby, które ponadprzeciętnie interesują się sprawami swojego regionu, „ojczyzny prywatnej”, by użyć klasycznego sformułowania autorstwa wybitnego polskiego socjologa St. Ossowskiego, czy w końcu swojej miejscowości, którą w przypadku uczestników naszych badań najczęściej jest duże miasto.

\section{Opis badanej zbiorowości}

W badaniach wzięło udział 819 respondentów, reprezentujących niemal wszystkie województwa (poza województwem kujawsko-pomorskim). Szczególnie nadreprezentowane jest województwo wielkopolskie (40,1\% ogółu badanych), kolejnymi województwami z punktu widzenia liczby respondentów są: województwo pomorskie $(13,4 \%)$, śląskie (11,4\%), mazowieckie (7,8\%), dolnośląskie (7,2\%), łódzkie (5,7\%). Pozostałe województwa uzyskały wynik poniżej $5 \%$. Z uwagi na relatywnie niski stopień reprezentatywności poszczególnych województw w badanej próbie, respondentów podzieliliśmy na pięć grup, które jak pokazują wyniki badań nad regionami politycznymi prowadzone przez politologów (Raciborski, 1997, s. 157-166) wydają się być zasadne. Pierwszą grupę tworzyli mieszkańcy Wielkopolski, którzy stanowią (40,1\% ogólnej liczby badanych). Drugą grupą są mieszkańcy „kongresówki”, czyli województw, których granice 
pokrywają się w większości (poza byłym województwem konińskim i kaliskim, które obecnie należą do Wielkopolski) z zasięgiem zaboru rosyjskiego. W naszych badaniach grupa ta liczyła 21\% wypełniających ankietę. Dodatkowo w przypadku tej grupy należy zauważyć, że większość respondentów, to mieszkańcy Warszawy, co niewątpliwie wpływa na udzielane odpowiedzi. Kolejną grupa, którą postanowiliśmy wyróżnić są mieszkańcy ziem zachodnich i północnych (województwa dolnośląskie, lubuskie, zachodniopomorskie, pomorskie i warmińsko-mazurskie). Z tego obszaru pochodziło $22,5 \%$ respondentów. Z uwagi na bardzo wyróżniające się wypowiedzi wypowiadających się pochodzących z terenu Górnego Śląska (województwo śląskie i opolskie) również tę grupę respondentów postanowiliśmy wyróżnić, mimo że nie była ona szczególnie liczna, gdyż stanowi ją jedynie 11,5\% ogółu badanych. Ostatnią, najmniej liczną, grupę stanowią mieszkańcy „zaboru austriackiego”. W badanej zbiorowości stanowią oni jedynie 4,9\% wszystkich, którzy wypełnili ankiety. Szkoda, że obszar ten jest tak bardzo niedoreprezentowany, gdyż wyróżnia się on w sposób szczególny od innych tym, że od początku transformacji społeczno-ustrojowej jest on bastionem środowisk konserwatywnych, regionem o silnym wpływie Kościoła katolickiego na zachowania politycznie w tym wyborcze jego mieszkańców.

Z uwagi na wiek respondentów podzieliliśmy na cztery grupy. Jednak podstawą wyróżnienia poszczególnych grup nie była, jak to się zwykle w badaniach społecznych czyni, data urodzenia. My zdecydowaliśmy, aby było to osiagnięcie przez respondentów wieku 16 lat. Przyjęliśmy bowiem, że od mniej więcej tego momentu świadomie uczestniczy się, a przynajmniej percepuje świat rzeczywistości społecznej. Pierwszą grupę w naszych badaniach stanowi pokolenie urodzone przed rokiem 1929, które nazwaliśmy „,pokoleniem II Rzeczpospolitej i pokoleniem wojny i okupacji”, respondenci tej grupy stanowiąjedynie $0,25 \%$ ogółu badanych ( 2 osoby). Fakt, że dokonaliśmy wyróżnienia tej grupy spowodowany jest tym, że respondenci ci mieli stanowić swego rodzaju „grupę kontrolną" jeśli chodzi o tradycyjne i współczesne definiowanie tego jak należy rozumieć patriotyzm. Jak się jednak okazało wyróżnienie tej kategorii nie było użyteczne z punktu widzenia prowadzonych analiz. Druga grupa, to respondenci nazwani przez nas ,,pokoleniem PRL-u", czyli osoby urodzone w latach 1930-1963. Ta grupa badanych to 21,1\% badanej populacji. Trzecią grupąjest tzw. ,pokolenie Solidarności”, czyli osoby urodzone w latach 1964-1973, stanowiące 15,26\% całości próby. Wyróżnienie tej grupy z ,pokolenia PRL-u” wynika z tego, że w momencie powstania „NSZZ Solidarność” byli oni już dorośli, a w całej dekadzie lat 80 . brali aktywny udział w procesach, które w roku 1989 doprowadziły do upadku komunizmu w Polsce. Ostatnia, czwarta grupa, najliczniej reprezentowana (63,69\% wszystkich badanych), to ,pokolenie III RP”, więc osoby urodzone po roku 1974.

Jeszcze inną zmienną, która z punktu widzenia tego projektu jest ważna, to miejsce zamieszkania uwzględniające wielkość miejscowości, w której mieszkają nasi respondenci. Z kolei przyjmując to kryterium podzieliliśmy ich na cztery grupy. Pierwsza grupa, to mieszkańcy tzw. „Polski lokalnej”, czyli osoby mieszkające w miejscowościach poniżej 25 tys. mieszkańców, stanowiący 30,28\% badanych. Druga, którą nazwaliśmy „grupą pośrednią", to mieszkańcy miast mieszczących się w przedziale 25-100 tys. mieszkańców, ta grupa respondentów stanowi 19,39\% ogółu populacji. „Duże miasta”, to trzecia grupa, w której znaleźli się ci uczestnicy naszego badania, którzy mieszkają 
w miastach liczących ponad 100 tys. mieszkańców. Jest to najliczniej reprezentowana grupa, gdyż obejmuje 47,49\% osób, które zdecydowały się wypełnić naszą ankietę. Spośród wszystkich respondentów jedynie $1,58 \%$ mieszka powyżej trzech miesięcy za granicą, oni stanowią czwartą, ostatnią grupę.

Jeszcze inną, istotną jak się wydaje $\mathrm{z}$ punktu widzenia problemu badawczego cechą badanych jest wykształcenie respondentów. W przypadku tej zmiennej problem nadreprezentatywności jest bodaj najbardziej widoczny, lecz z drugiej strony oczywisty z uwagi na fakt, że aby wziąć udział w badaniach należało mieć dostęp do internetu i choć na minimalnym poziomie umiejętność rozumienia treści merytorycznych kwestionariusza $\mathrm{i}$ instrukcji udzielania odpowiedzi. Umiejętności te niekoniecznie posiadają osoby o niższym wykształceniu. Zdecydowana większość uczestników naszych badań legitymuje się wykształceniem wyższym $51,76 \%$, wykształcenie licencjackie posiada $11,39 \%$ badanych, średnie $24,24 \%$, zawodowe $3,39 \%$, a podstawowe $2,06 \%$.

Ostatnią ze zmiennych, która, w naszym przekonaniu, warunkuje rozumienie tego czym jest patriotyzm i czym powinien charakteryzować się patriota, są poglądy polityczne badanych. Poglądy prawicowo-konserwatywne deklaruje $15,88 \%$ badanych poglądy liberalne (w wersji prawicowej «22,42\%» i lewicowej «13,94\%») deklaruje 36,36\% uczestników naszych badań, poglądy lewicowe $4,85 \%$ respondentów. Brak sprecyzowanych poglądów stwierdza 12,97\% respondentów, z kolei 12,61\% uchyliło się od udzielenia odpowiedzi na to pytanie. Odpowiedzi na pytania o poglądy polityczne pokrywają się najogólniej z odpowiedziami na pytanie o to na jakie partie polityczne respondenci głosowali podczas ostatnich wyborów parlamentarnych z roku 2011. Można więc przyjąć, że w pierwszej grupie znajdują się respondenci Prawa i Sprawiedliwości, w drugiej wyborcy Platformy Obywatelskiej, a w trzeciej Sojuszu Lewicy Demokratycznej.

Zmienna, którą zwykle uwzględnia się w większości badań prowadzonych przez nauki społeczne jest płeć respondentów. My również zapytaliśmy o to w naszej ankiecie, i tak wśród badanych dominowali mężczyźni - 65\%, a kobiety stanowiły jedynie $35 \%$ ogółu wypowiadających się. Analiza wypowiedzi tej grupy wykazała jednak, że wpływ tej zmiennej był nieistotny z punktu widzenia problemu badawczego, dlatego została ona pominięta $\mathrm{w}$ analizach tego raportu.

\section{Wyniki badań}

Jak już zostało wcześniej podkreślone organizatorzy badań zostali pozytywnie zaskoczeni odzewem, z jakim pomysł przeprowadzenia badań na ten temat spotkał się u odwiedzających portal NaszeMiasto.pl. Równie zaskakujące było to, że respondenci chętnie dzielili się swoimi uwagami przy okazji udzielania odpowiedzi na poszczególne pytania kwestionariusza ankiety. Zebrany materiał jest niezwykle bogaty w wiedzę na temat postrzegania patriotyzmu w ogóle, w tym patriotyzmu regionalnego.

Badania zostały podzielone na trzy części. W pierwszej starliśmy się znaleźć odpowiedź na pytanie: jak nasi respondenci rozumieją patriotyzm? Jak wcześniej wspomniano w tym celu wykorzystaliśmy kategorie opisujące patriotyzm, do których w swoich badaniach odwołali się autorzy badań prowadzonych w roku 2008 przez Centrum Badania Opinii Publicznej (Rozumienie). 
Drugim obszarem w naszych badaniach były pytania o to, jak badani postrzegają regionalizm lokalny? Tu szczególnie trudno było zoperacjonalizować pytania z uwagi na fakt, że wielu respondentów deklarowało więcej niż jedną tożsamość, trudno było określić granice regionu, do których w swoich ocenach powinni odnosić się respondenci. Szczególnie respondenci mieszkający za granicą formułowali zarzut, że narzędzie to ich marginalizuje. Jednak generalna uwaga, jaka nasuwa się po analizie odpowiedzi na to pytanie, jest taka, że respondenci zwykle wykorzystywali wszystkie możliwości (zawsze mieli do wyboru trzy), aby określić czym wyróżnia się ich region w stosunku do innych regionów Polski.

W trzeciej części staraliśmy się zdiagnozować na ile nasi respondenci oceniają swoje postawy jako postawy, które powinny charakteryzować patriotę lokalnego. Założyliśmy bowiem, że większość badanych określi się jako patrioci lokalni, czego jednak badania w sposób jednoznaczny nie potwierdziły, gdyż tego typu deklarację złożyła mniej niż połowa wypełniających ankietę. Dotyczy to głównie mieszkańców, w pewnym sensie „,nowych”, z punktu widzenia procesów związanych z definiowaniem tożsamości regionalnej obszarów, nazywanych nadal często ziemiami zachodnimi i północnymi.

\section{Patriotyzm w ogóle}

Niemal wszystkie kategorie, które wykorzystaliśmy z badania prowadzonego przez CBOS znalazły potwierdzenie jako bardzo ważne czy ważne w definiowaniu patriotyzmu. Najważniejsze spośród nich, czyli takie które uzyskały ponad 80\% wskazań (wyborów kategorii ,zdecydowanie tak” bądź kategorii „tak”) to, miłość do ojczyzny, duma ze swego kraju, znajomość historii Polski, obrona dobrego imienia ojczyzny, szacunek do symboli narodowych (hymn, godło, flaga), dbałość o zachowanie języka, dbałość o wychowanie dzieci na „dobrych” Polaków (znających historię swojego państwa i narodu), prawo do wyrażania sprzeciwu wobec tych decyzji władz, z którymi badani się nie zgadzają. Na przeciwnej pozycji znalazły się kategorie, które uzyskały 50\% odrzuceń (wyborów kategorii „nie” bądź kategorii „zdecydowanie, nie”), czyli, systematyczne chodzenie do kościoła, przestrzeganie wartości chrześcijańskich, bycie lojalnym „obywatelem” Unii Europejskiej, mieszkanie przez całe życie w Polsce, zaufanie do demokratycznie wybranych przedstawicieli w rozumieniu polityków. W przypadku pytania o to, czy zaufanie do demokratycznie wybranych polityków powinno być traktowane jako przejaw patriotyzmu, najbardziej krytyczne jest pokolenie nazwane przez nas ,,pokoleniem Solidarności”, gdyż jedynie $17 \%$ badanych zgodziło się z tą opinią, gdy w przypadku ,pokolenia PRL" tego zdania jest 29\% respondentów, a z ,pokolenia III RP” pogląd ten podziela $20 \%$ badanych. Wydaje się, że taki rozkład odpowiedzi jest wynikiem, z jednej strony zawodu ze sposobu uprawiania polityki przez elity, jaki jest udziałem pokolenia, które dokonało przełomu. Zawód ten jest o tyle zasadny, że od niemal dziesięciu lat władzę w Polsce sprawują partie wywodzące się z nurtu solidarnościowego. Z drugiej strony zapewne mamy do czynienia ze spadkiem znaczenia polityki i polityków w życiu społecznym w ogóle.

Kolejnym ważnym wskaźnikiem dystansowania się Polaków od świata polityki jest rozkład odpowiedzi na pytanie, czy miarą patriotyzmu jest udział w uroczystościach na- 
rodowych organizowanych przez władze państwowe? Z opinią tą zgodziło się jedynie $41 \%$ pytanych, nie potrafiło jednoznacznie ustosunkować się to tego pytania (wybór kategorii ,trudno powiedzieć”) 28\% respondentów, sprzeciwiło się tej opinii 31\% osób udzielających odpowiedzi.

Od wielu lat Polacy należą do najbardziej proeuropejskich społeczeństw Unii Europejskiej, poparcie dla członkostwa Polski w UE sięga niemal 80\%. Jeśli dodatkowo podkreślić, że zwolennikami tego członkostwa są dobrze wykształceni mieszkańcy dużych miast, którzy stanowią większość w badanej przez nas zbiorowości, to zastanawiające wydaje się to, że jedynie $21 \%$ wskazuje na bycie lojalnym „obywatelem” Unii Europejskiej jako jeden z wyznaczników patriotyzmu. Nie jest zaskakujące, że największymi przeciwnikami takiego rozumienia patriotyzmu są wyborcy Prawa i Sprawiedliwości, spośród których jedynie 13\% zgadza się z taką opinią, gdy spośród wyborców Sojuszu Lewicy Demokratycznej pogląd ten popiera niemal 31\% pytanych, a spośród wyborców Platformy Obywatelskiej niemal 28\% zgodziło się z nim.

Kościół katolicki w Polsce od stuleci był nośnikiem wartości patriotycznych, tak było w okresie rozbiorów, w okresie odbudowy państwowości polskiej w dwudziestoleciu międzywojennym jak i przede wszystkim w latach 1948-1989. Dlatego zaskakujące wydaje się to, że na przestrzeganie wartości chrześcijańskich jako przejaw patriotyzmu wskazuje, ,jedynie” 36\% badanych, natomiast na uczęszczanie do kościoła 18\%. Nietrudno się domyślić, że wyborcy Prawa i Sprawiedliwości mieszkający w „Polsce lokalnej” traktują udział w mszach świętych i przestrzeganie norm społecznych inspirowanych dekalogiem jako przejaw patriotyzmu. Z kolei mieszkający w dużych miastach wyborcy, przede wszystkim Platformy Obywatelskiej, najczęściej odżegnują się od takich wskaźników patriotyzmu.

Trudno jednoznacznie rozstrzygnąć, czy za przejaw patriotyzmu można przyjąć fakt, że 55\% naszych badanych wskazało na uczciwe płacenie podatków, w badaniach CBOS-u taką deklarację złożyło 68\% (Rozumienie, s. 6) badanych. Jeśli skonfrontować tę odpowiedź z innymi odpowiedziami, opisującymi stosunek wypowiadających się do państwa (udział w uroczystościach organizowanych przez władze, przestrzeganie prawa, prawo do wyrażania sprzeciwu z decyzjami, z którymi się nie zgadzamy, zaufanie do wybranych przedstawicieli), to należy stwierdzić, że jest to jeszcze jeden ze wskaźników niskiego zaufania do instytucji państwa i jej przedstawicieli, czyli polityków.

W kontekście wydarzeń, jakie mają miejsce na Ukrainie zasadnym wydaje się spojrzenie na poświęcenie życia dla ojczyzny jako jeden z najważniejszych wskaźników patriotyzmu. Dla wielu pokoleń Polaków, zwłaszcza tych, których życie przypadło na okres zaborów taki wskaźnik patriotyzmu wydałby się bezdyskusyjny. Podobnie jest dla pytanych o patriotyzm w 2008 roku przez CBOS, spośród których gotowość walki i poświęcenia życia za ojczyznę deklarowało 90\% (Rozumienie, s. 6) respondentów. W naszych badania gotowość do tego, aby ,gdy zajdzie taka potrzeba oddać życie w obronie kraju” zadeklarowało $58 \%$ pytanych. Gotowość do takiego poświęcenia deklaruje $78 \%$ (sic!) wyborców Prawa i Sprawiedliwości, a spośród elektoratu Platformy Obywatelskiej ,,jedynie" 49\%. Miejsce zamieszkania, wykształcenie, nie miały istotniejszego wpływu na udzielane odpowiedzi na to pytanie.

Drugim pytaniem z grupy pytań o wyobrażenie tego czym jest patriotyzm i jak powinien się przejawiać było pytanie o to: Kto zdaniem naszych respondentów współcześnie 
jest największym patriotą? Najwięcej wyborów otrzymała kategoria „obywatele, którzy rzetelnie pracują i wywiązują się z obowiązków wobec państwa”, $62 \%$ wskazań. Wynik ten jest sprzeczny jednak z odpowiedziami, które wskazywali respondenci w poprzednim pytaniu, gdy twierdzili, że ,uczciwe płacenie podatków” nie jest koniecznie wskaźnikiem patriotyzmu. Pozostałe kategorie otrzymały o około połowę mniej wyborów, i tak na drugim miejscu, z 27\% wskazań znaleźli się ,, ci politycy, którzy dopominają się o godne miejsce Polski na arenie międzynarodowej”, kolejna grupą są ,,przedsiębiorcy, bo prowadząc firmę przyczyniają się do wzrostu poziomu życia innych" (26\% wskazań). W tej grupie znaleźli się również ,polscy żołnierze wyjeżdżający na misje pokojowe” $(22 \%$ wyborów).

Na przeciwnym biegunie, z punktu widzenia oceny postaw patriotycznych, znaleźli się , ,i wszyscy, którzy wyjechali z Polski do pracy za granicę” (3\% wskazań) i , „hierarchowie kościoła, gdyż stoją na straży najważniejszych dla wszystkich Polaków wartości” ( $8 \%$ wskazań). W tym przypadku potwierdzone zostały wyniki z poprzedniego pytania, kiedy to chodzenie do kościoła i przestrzeganie zasad dekalogu niekoniecznie traktowane jest przez naszych badanych jako postawy świadczące o patriotyzmie. Wydaje się, że jest to cena, jaką płaci kościół w Polsce za zaangażowanie się w spory politycznie i światopoglądowe, które są udziałem polskiego społeczeństwa. Nie chodzi tylko o angażowanie się, lecz również opowiadanie się wyraźnie po jednej ze stron sporu. Jedynie mieszkający w „Polsce lokalnej” wyborcy Prawa i Sprawiedliwości, którzy najczęściej mają światopogląd prawicowo-konserwatywny, wskazują na ważną rolę pełnioną przez hierarchów kościoła w kształtowaniu postaw patriotycznych. Tylko 1,6\% wyborców Platformy Obywatelskiej zgodziło się z opinia, że ,hierarchowie stojąc na straży najważniejszych dla wszystkich Polaków wartości" przyczyniają się do kształtowania się postaw patriotycznych. Wśród wyborców Prawa i Sprawiedliwości z poglądem tym zgodziło się aż 32\% respondentów. Zastanawiające jest, że z opinią tą zgodziło się jedynie $18 \%$ wyborców Polskiego Stronnictwa Ludowego.

\section{Patriotyzm regionalny (lokalny)}

Pytaniem wprowadzającym do tej części badań było pytanie o to jak respondenci oceniają zmiany, które zaszły w Polsce, w ich regionie i w ich miejscowości? Generalny wniosek, jaki można sformułować analizując udzielone odpowiedzi jest taki, że ,pokolenie PRL-u" najlepiej ocenia zmiany, jakie zaszły zarówno w Polsce, jak i w regionach i miejscowościach, w których mieszkają. Najmniej entuzjastycznie przemiany te ocenia „pokolenie III RP”. Lecz różnice nie są w jakiś znaczący sposób istotne, w każdej grupie około $50 \%$ respondentów pozytywnie ocenia szansę, przed jaką stanęło społeczeństwo polskie po odzyskaniu suwerenności. Sytuacja zmienia się gdy zmienną, którą uwzględnimy są poglądy respondentów. Najbardziej krytyczni w ocenie przemian są respondenci i poglądach prawicowo-konserwatywnych. Tylko $16,3 \%$ spośród nich pozytywnie ocenia zmiany na poziomie ogólnopolskim, nieco mniej krytyczni są oni, gdy pytamy o poziom regionu, wówczas ocen pozytywnych jest już 30\%, podobnie jest, gdy pytamy o zmiany na poziomie miejscowości, wówczas poziom zadowolenia wzrasta do $26 \%$. $\mathrm{W}$ porównaniu z tymi opiniami oceny formułowane przez respondentów o poglądach 
prawicowo-liberalnych czy lewicowo-liberalnych są radykalnie różne. Pozytywnie przemiany w Polsce ocenia 54\% respondentów o poglądach prawicowo-liberalnych, a $68 \%$ o poglądach lewicowo-liberalnych, na poziomie regionu odpowiednio wartości te wynosza, $61 \%, 69 \%$, a z kolei na poziomie miejscowości, w której mieszkają nasi respondenci pozytywnie zmiany ocenia $52 \%$ respondentów i poglądach prawicowo-literalnych i 65\% respondentów deklarujących poglądy lewicowo-liberalnych. Respondenci o poglądach lewicowych są tylko nieznacznie bardziej krytyczni w ocenie przemian od liberałów. Tak wyraźna różnica w ocenach efektów przemian między wyborcami deklarującymi poglądy prawicowe w stosunku do respondentów o poglądach liberalnych jest jak się wydaje pochodną podziału na „Polskę liberalną” i „Polskę solidarną”, a więc Polskę, która wybiera Platformę Obywatelską lub Prawo i Sprawiedliwość.

Jeśli chodzi o postrzeganie przemian widzianych z perspektywy regionu zamieszkania, to nieznacznie więcej pozytywnych ocen tych przemian na każdym poziomie (Polska, region, miejscowość w której mieszkają respondenci) deklarują mieszkańcy ziem zachodnich i północnych oraz Wielkopolski w stosunku do pozostałych regionów.

Drugim pytaniem wśród pytań o patriotyzm lokalny, było pytanie o to, z jakim miejscem (miejscowość w której mieszkają, region, Polska, Europa, cały świat) nasi badani identyfikują się przede wszystkim? Niemal połowa (48\%) wskazało na poziom regionalny, który tworzą miejscowość, w której mieszkają respondenci (15,76\%), mała ojczyzna w rozumieniu najbliższa okolica $(12,12 \%)$, region w którym mieszkają nasi respondenci $(20,48 \%)$. Polska jako poziom identyfikacji to wybór 35\% respondentów. Jako obywatele Europy deklaruje się ,jedynie" $10 \%$ respondentów, są to głównie wykształceni młodzi ludzie. Siłę ,przywiązania” do miejsca zamieszkania diagnozowało pytanie o to czy respondenci, gdyby była taka możliwość, zmieniliby to miejsce. Niechęć do zmiany miejsca zamieszkania zadeklarowało $52 \%$ respondentów, ewentualny wyjazd do innej miejscowości w regionie zadeklarowało 10\% badanych, do innego regionu Polski $9 \%$. Natomiast na państwo Unii Europejskiej jako cel ewentualnego wyjazdu wskazało jedynie 17\% respondentów. Do Europy, lecz do państwa innego niż kraj członkowski Unii Europejskiej wskazało 2\% udzielających odpowiedzi, a poza Europę 7\%. Najsilniej związani z miejscem zamieszkania czują się respondenci pochodzący z dużych miast.

Najbardziej interesujące wyniki, jeśli chodzi o definiowanie poziomu swojej identyfikacji przynosi porównanie tej identyfikacji z regionem zamieszkania respondentów (tabela 1).

$\mathrm{Z}$ jakim miejscem na ziemi identyfikują się respondenci

Tabela 1

\begin{tabular}{||l|c|c|c|c|c||}
\hline \multicolumn{1}{|c|}{ Poziom identyfikacji } & Galicja & Kongresówka & Górny Śląsk & Wielkopolska & ZZiP \\
\hline Miejscowość, w której mieszkam & 17,5 & 16,9 & 8,5 & 16,7 & 15,8 \\
\hline Mała ojczyzna (najbliższa okolica) & 12,5 & 7,6 & 10,6 & 14,9 & 12,0 \\
\hline Region & 20,0 & 8,1 & 34,0 & 26,4 & 14,7 \\
\hline Polska & 30,0 & 47,7 & 30,9 & 28,3 & 37,5 \\
\hline Europa & 12,5 & 10,5 & 7,4 & 9,4 & 9,8 \\
\hline Jestem obywatelem świata & 5,0 & 8,7 & 6,4 & 3,6 & 7,1 \\
\hline Inne & 2,5 & 0,6 & 2,1 & 0,6 & 3,3 \\
\hline
\end{tabular}

Źródło: Opracowanie własne na podstawie wyników badań. 
Jak zaznaczono, regionami, z którymi mieszkańcy najsilniej się identyfikują są Górny Śląsk i Wielkopolska. Zależność ta jest jeszcze wyraźniej widoczna jeśli zsumujemy wyniki trzech pierwszych poziomów identyfikacji (miejscowość, mała ojczyzna, region), wówczas dla Galicji wartość ta będzie wynosić 50\%, dla Kongresówki 32,6\%, dla Górnego Śląska 53\%, dla Wielkopolski 56,2\%, dla ZZiP 42,5\%. Co oznaczają te wyniki? Potwierdzają tendencje zaobserwowane w trakcie dyskusji, jaka toczyła się w Polsce na temat kształtu reformy administracyjnej w latach 90. ubiegłego wieku. Wizje utworzenia silnych, samodzielnych województw regionów na wzór landów niemieckich, były i nadal są najsilniejsze właśnie w tych dwóch regionach. Z kolei ziemie zachodnie i północne są dopiero w trakcie trwania skomplikowanego procesu definiowana odrębności regionalnej stąd relatywnie niski poziom identyfikacji respondentów pochodzących z tych terenów $\mathrm{z}$ regionem.

W kolejnym pytaniu tej części ankiety pytaliśmy o „cechy”, którymi powinna charakteryzować się osoba określająca się mianem patrioty lokalnego. Niemal wszystkie zaproponowane przez nas kategorie uzyskały ponad 50\% wyborów (,zdecydowanie tak” i ,tak”). Najważniejsze z nich to: ,angażowanie się w sprawy ważne dla regionu” (89\%), „wspieranie działań przyczyniających się do rozwoju regionu” (88\%), ,znajomość historii regionu” (87\%), ,wiedza na temat postaci związanych z regionem” $(81 \%)$, „udział przede wszystkim w wyborach samorządowych” (73\%), ,kupowanie produktów regionalnych” (64\%), ,znajomość potraw regionalnych” (63\%). Najniżej, na „liście” pożądanych dla patrioty lokalnego cech, znajduje się: ,przedkładanie interesów regionu ponad interesy kraju". Rozkład odpowiedzi na to pytanie w porównaniu z wyróżnionymi regionami przedstawiony został $\mathrm{w}$ tabeli 2 .

Tabela 2

Czy należy przedkładać interesy regionu ponad interesy kraju? [w \%]

\begin{tabular}{||l|c|c|c|c|c||}
\hline \hline & Galicja & Kongresówka & Górny Śląsk & Wielkopolska & ZZiP \\
\hline Zdecydowanie tak & 15,0 & 5,8 & 20,2 & 11,2 & 4,3 \\
\hline Tak & 12,5 & 13,4 & 16,0 & 15,2 & 13,0 \\
\hline Trudno powiedzieć & 20,0 & 37,8 & 38,3 & 34,7 & 37,5 \\
\hline Nie & 35,0 & 30,2 & 14,9 & 26,7 & 31,5 \\
\hline Zdecydowanie nie & 17,5 & 12,8 & 10,6 & 12,2 & 13,6 \\
\hline
\end{tabular}

Źródło: Opracowanie własne na podstawie wyników badań.

Jednak również w przypadku tego pytania wyraźnie zauważalna jest odrębność Górnego Śląska, którego mieszkańcy, najczęściej rodowici Górnoślązacy, formułują pogląd, że region ten jest eksploatowany i aby się temu przeciwstawić część z nich postuluje powrót do rozwiązań z okresu dwudziestolecia międzywojennego, kiedy to województwo śląskie miało daleko idącą autonomię.

Z kolei na ,przedkładanie interesów swego regionu ponad interesy innych regionów”, jako jedną z cech, którą powinien charakteryzować się patriota wskazało 37\% respondentów, a na ,głosowanie na polityków pochodzących z regionu” 43\% spośród nich. Pobieżny ogląd rozkładu odpowiedzi na to pytanie wskazuje, że respondenci nie są,,szo- 
winistami regionalnymi”, przede wszystkim postrzegają swój region jako element większej całości, jaką jest państwo polskie. Wyjątkiem wydaje się być Górny Śląsk, który po raz pierwszy w swojej historii ma szansę na to, aby wyartykułować swoją odrębność i zmusić władze państwa, którego częścią aktualnie jest ten region do jej zauważenia i respektowania.

Grupa pytań o rozumienie patriotyzmu lokalnego były również pytania, których celem było poznanie na ile respondenci są w stanie wskazać przejawy odrębności lokalnej regionów, w których mieszkają. Wszystkie one otrzymały pozytywne odpowiedzi na poziomie przekraczającym 60\% wskazań. Gdy pytaliśmy, czy są jakieś cechy, które wyróżniają ich region $63 \%$ respondentów udzieliło odpowiedzi twierdzącej, wskazując głównie na cechy jego mieszkańców (pracowitość, gospodarność), odrębność kulturowa (gwara), cechy geograficzne (krajobraz, zasoby naturalne) (tabela 3).

Tabela 3

Czy są cechy, które odróżniają region, w którym Pan/i mieszka od innych regionów Polski? [w \%]

\begin{tabular}{||l|c|c|c|c|c||}
\hline & Galicja & Kongresówka & Górny Śląsk & Wielkopolska & ZZiP \\
\hline Tak & 40,0 & 54,7 & 79,8 & 63,2 & 68,5 \\
\hline Nie & 60,0 & 45,3 & 20,2 & 36,8 & 31,5 \\
\hline
\end{tabular}

Źródło: Opracowanie własne na podstawie wyników badań.

Podobnie jak w poprzednich pytaniach tej części ankiety najwyraźniej swoją odrębność, względem innych społeczności regionalnych zamieszkujących współczesną Polskę artykułują Górnoślązacy, spośród których ponad $24 \%$ wskazuje na różnice kulturowe takie jak: język, mentalność, kuchnia. Niemal 11,9\% eksponuje takie cechy charakteru jak pracowitość, zamiłowanie do porządku. Na trzecim miejscu znalazło się przekonanie o odrębnej historii tego regionu, 9,4\% wskazań, innej niż ta prezentowana przez polską szkołę.

Jednak grupą, która najwyraźniej artykułuje swoją odrębność z punktu widzenia cech regionalnych, uznawanych przez jej członków za pozytywne, są Wielkopolanie, spośród których 36\% wskazuje na takie cechy jak pracowitość, zamiłowanie do porządku, oszczędność, gospodarność. Podobnie jak Górnoślązacy, Wielkopolanie twierdza, że wyróżnia ich od mieszkańców innych regionów ich gwara i kuchnia regionalna $(10,1 \%$ wskazań).

Innym pytaniem, którego celem było wysondowanie jak mieszkańcy poszczególnych regionów definiują swoją odrębność regionalną było pytanie o produkty i potrawy regionalne. Pozytywnej odpowiedzi udzieliło $65 \%$ respondentów. Pełna lista - z uwagi na mnogość - jest trudna do sporządzenia, jednak ciekawe jest to, że niektóre produkty i potrawy kojarzone powszechnie z jakimś regionem Polski występują jako regionalne wyróżniki $\mathrm{w}$ innych regionach. Jest to niewątpliwie pokłosie wielkich procesów migracyjnych z lat 40. i 50. ubiegłego wieku. Zdecydowanie najtrudniej jest wskazać na tego typu produkty i potrawy mieszkańcom ziem zachodnich i północnych, którzy zwykle przytaczają przykłady potraw pochodzacych z kuchni kresowej.

Ostatnim pytaniem w tej grupie było pytanie o znajomość jakiegoś wydarzenia, święta czy postaci ściśle związanej z regionem zamieszkania udzielających odpowiedzi. 
W przypadku tego pytania aż 74\% respondentów udzieliło twierdzącej odpowiedzi. Dominują powstania warszawskie, wielkopolskie, śląskie i postaci związane z historią Polski, jednak zdaniem respondentów związane są one przede wszystkim z historią ich regionów (Roman Dmowski, Julian Tuwim, Jan III Sobieski, Artur Rubinstein). Prezentowanie wyników odpowiedzi na to pytanie ankiety ma charakter opisowy, z uwagi na fakt, że respondenci mogli wskazać trzy odpowiedzi, z czego nie wszyscy skorzystali. Tak więc zliczanie jak często pojawiała się dana odpowiedź nie wydaje się zasadne metodologicznie.

W przypadku tego pytania grupą, która najwyraźniej zaznaczyła swoją tożsamość ponownie byli Wielkopolanie, dla których najważniejszym wydarzeniem na które wskazywali było powstanie wielkopolskie, które często było określane mianem jedynego zwycięskiego, to znaczy takiego, które osiągnęło zamierzone cele militarne i polityczne. Innym „wydarzeniem”, równie często przywoływanym przez respondentów pochodzących z Wielkopolski była XIX-wieczna tradycja pracy organicznej, a przy tej okazji wskazywali oni przede wszystkim na postać Hipolita Cegielskiego i innych przedstawicieli tej formacji (Karol Marcinkowski, Dezydery Chłapowski). Z kolei świętem, na które wskazywali nasi respondenci pochodzący z Wielkopolski jest 11 listopada, jednak nie jako święto niepodległości, lecz święto Św. Marcina. Wydarzeniem, na które respondenci z Wielkopolski często wskazują jest protest robotników z czerwca 1956 roku. Natomiast stosunkowo rzadko wśród postaci wyróżniających Wielkopolskę od innych regionów Polski pojawiają się postaci związane z polityką, kulturą czy sportem.

Górnoślązacy, podobnie jak Wielkopolanie, wskazują na powstania śląskie, jako wydarzenia wyróżniające ich region od innych, z tym, że inna, jak w przypadku Wielkopolski, jest ocena powstań. Nie są one traktowane jednoznacznie jak zrywy narodowe, lecz raczej w kategoriach tragedii tego regionu, w trakcie której doszło do bratobójczych walk. Postacie, na które wskazują respondenci pochodzący z tego regionu zwykle związane są z polityką. Najczęściej wymieniany jest przy tej okazji Wojciech Korfanty jako przywódca Górnoślązaków w walce zarówno z Niemcami, jak i z polskim rządem sanacyjnym. Najważniejszym świętem na Górnym Śląsku jest oczywiście Barbórka. W przypadku tej grupy respondentów obok postaci historycznych pojawiają się postaci współczesne związane głównie z kulturą (Ryszard Riedel legendarny lider zespołu „Dżem”, Kazimierz Kutz) i sportem (Jerzy Kukuczka wybitny himalaista).

Trzecią grupą obok wyżej wyróżnionych, która zaznaczyła wyraźnie swoją odrębność są mieszkańcy województw, które kiedyś były częścią Królestwa Kongresowego, wśród których dominują mieszkańcy Warszawy. Podobnie jak w przypadku dwóch poprzednich grup najważniejszym wydarzeniem, na które wskazują jest powstanie warszawskie, ale również powstania narodowe z XIX wieku, na które nie wskazują mieszkańcy innych regionów Polski. Wśród najważniejszych „postaci regionalnych” są postaci historyczne związane z kulturą, z tym, że respondenci tej grupy równie często wskazują na wielkie postaci historyczne związane z polityką.

Omówione powyżej regiony mają wyraźne, długotrwałe tradycje wpisane w ich historię. $Z$ inną sytuacją mamy do czynienia w przypadku ziem zachodnich i północnych, których związki z Polską zaczęły się dopiero po roku 1945. Dlatego respondenci pochodzący z tych ziem odwołują się raczej do postaci i wydarzeń o relatywnie krótkiej historii. Wydarzeniami, na które wskazują mieszkańcy Dolnego Śląska, Ziemi Lubuskiej, woje- 
wództwa zachodniopomorskiego i pomorskiego są różnego rodzaju festiwale, jarmarki i święta lokalne o krótkiej tradycji. Jeśli wskazują na jakieś postaci historyczne, to są to postaci związane historią lub kulturą polską w ogóle. Jest to zrozumiałe z uwagi na fakt, że jak to zostało powiedziane powyżej, są to społeczności nadal in statu nascendi. W tej grupie respondentów często pojawiają się postaci związane ze współczesnością i wówczas zwykle są to politycy samorządowi, prezydenci miast, członkowie rządu pochodzący $z$ danego regionu.

Na uwagę zasługuje również to, że postaci związane z Kościołem wymieniane są jako ważne postaci związane $\mathrm{z}$ regionem jedynie przez respondentów pochodzących $\mathrm{z}$ województw, które niegdyśs stanowiły zabór austro-węgierski. Ta grupa respondentów często wskazywała na postaci historyczne związane z polityką.

\section{Ocena badanych wlasnego patriotyzmu}

Jednym z pytań tego obszaru było pytanie o subiektywną ocenę tego czy badani czują się patriotami lokalnymi. Niemal połowa pytanych $(49,33 \%)$ potwierdziło taką afiliację, jednak zastanawiające jest to, że 35\% badanych uchyliło się od jednoznacznej odpowiedzi na to pytanie wybierając odpowiedź ,trudno jest mi to ocenić". Tylko $15 \%$ jednoznacznie nie określiło się mianem patrioty lokalnego. Dowodem na bycie patriotą lokalnym jest znajomość historii swego regionu, udział w wydarzeniach związanych ze swoim regionem oraz reagowanie na oceny dotyczące regionu, $\mathrm{z}$ których pochodzą respondenci: ,[...] tak to się objawia, że: a) dostaję wypieków na twarzy z radości, gdy ktoś chwali mój region, b) dostaję wypieków na twarzy ze złości, gdy ktoś niesłusznie krytykuje mój region, c) dostaję wypieków na twarzy ze wstydu, gdy ktoś słusznie krytykuje mój region (188/Śl)".

Tabela 4

W czym przejawia się Pana/i patriotyzm lokalny? [w \%]

\begin{tabular}{|l|c|c|c|c|c||}
\hline & Galicja & $\begin{array}{c}\text { Kongre- } \\
\text { sówka }\end{array}$ & $\begin{array}{c}\text { Górny } \\
\text { Śląsk }\end{array}$ & $\begin{array}{c}\text { Wielko- } \\
\text { polska }\end{array}$ & ZZiP \\
\hline \multicolumn{1}{|c|}{1} & 2 & 3 & 4 & 5 & 6 \\
\hline Zdobywam i przekazuję wiedzę na temat mojego regionu & 5,0 & 10,5 & 13,8 & 12,5 & 13,0 \\
\hline Uczestniczę w życiu mojego regionu/miasta & 2,5 & 6,4 & 2,1 & 6,1 & 8,7 \\
\hline Dbam o porządek i środowisko naturalne & 0,0 & 0,6 & 0,0 & 0,6 & 0,5 \\
\hline Dbam o dobre imię mieszkańców mojego regionu & 2,5 & 0,6 & 0,0 & 1,8 & 1,1 \\
\hline $\begin{array}{l}\text { Wspieram lokalnych producentów, kupuję lokalne pro- } \\
\text { dukty }\end{array}$ & 0,0 & 1,2 & 1,1 & 1,5 & 0,5 \\
\hline $\begin{array}{l}\text { Popularyzuję wiedzę o regionie (wykłady, książki, arty- } \\
\text { kuły) }\end{array}$ & 0,0 & 0,6 & 2,1 & 2,1 & 2,7 \\
\hline Kibicuję drużynom sportowym pochodzącym z regionu & 0,0 & 1,2 & 0,0 & 0,6 & 1,1 \\
\hline Jestem dumny ze swojego regionu/miasta & 7,5 & 1,2 & 4,3 & 3,6 & 2,2 \\
\hline Promuję język i symbole regionalne & 0,0 & 0,0 & 6,4 & 0,9 & 2,2 \\
\hline Jestem przede wszystkim mieszkańcem regionu & 5,0 & 1,2 & 2,1 & 0,6 & 0,5 \\
\hline
\end{tabular}




\begin{tabular}{||l|r|r|r|r|r||}
\hline \multicolumn{1}{|c|}{1} & 2 & 3 & 4 & 5 & 6 \\
\hline $\begin{array}{l}\text { Kultywuję pamięć o tych, którzy walczyli o mój re- } \\
\text { gion/miasto }\end{array}$ & 0,0 & 0,0 & 2,1 & 1,8 & 0,5 \\
\hline Wspieram, działam w organizacjach lokalnych & 0,0 & 0,0 & 3,2 & 1,2 & 1,6 \\
\hline Biorę udział w wyborach samorządowych & 2,5 & 4,7 & 0,0 & 0,0 & 1,6 \\
\hline Pomagam innym mieszkańcom regionu/miasta & 0,0 & 1,2 & 0,0 & 0,0 & 1,1 \\
\hline Po prostu kocham swój region/miasto & 0,0 & 2,3 & 2,1 & 4,0 & 1,6 \\
\hline Brak uzasadnienia & 45,0 & 42,4 & 40,4 & 44,1 & 37,0 \\
\hline $\begin{array}{l}\text { Jestem dobrym obywatele, uczciwy, pracowity, płacę } \\
\text { podatki }\end{array}$ & 0,0 & 1,7 & 0,0 & 0,9 & 2,7 \\
\hline Inne odpowiedzi & 2,5 & 8,1 & 5,3 & 5,5 & 4,9 \\
\hline
\end{tabular}

Źródło: Opracowanie własne na podstawie wyników badań.

Jedno z pytań, które skierowane było do respondentów, którzy uważają siebie za patriotów lokalnych dotyczyło tego w czym przejawia się ich patriotyzm. Rozkład odpowiedzi na to pytanie zawiera tabela 4. Jak widać najczęstszą formą okazywania patriotyzmu regionalnego jest zdobywanie wiedzy o swoim regionie i przekazywanie jej dalej znajomym, członkom rodziny. $Z$ tą formą patriotyzmu regionalnego spotykamy się niemal we wszystkich regionach. Inną formą jest aktywny udział w życiu miasta, w wydarzeniach organizowanych przez władze. Jeszcze inną formą tego patriotyzmu jest popularyzowanie zgromadzonej wiedzy poprzez wykłady, publikowanie w lokalnej prasie, tworzenie opracowań na temat historii regionu. Na Górnym Śląsku respondenci wskazywali na popularyzowanie języka i symboli regionalnych, jako jednych z najważniejszych elementów konstytuujących tożsamość regionalną, o której uznanie zabiegają zwłaszcza działacze regionalni związani między innymi z Ruchem Autonomii Śląska.

Analiza odpowiedzi na pytanie o wydarzenia, które były organizowane w ich regionach, w których uczestniczyli nasi respondenci prowadzi do wniosku, że mieszkańcy „Polski lokalnej” i średnich miast częściej uczestniczą w wydarzeniach związanych z regionem. Taki pogląd wyraziło niemal $60 \%$ respondentów pochodzących z tej grupy. Jest to niemal dwukrotnie więcej niż mieszkańców wielkich miast, w których tego typu wydarzenia trudniej jest zorganizować.

Tabela 5

Udzial w organizowanych przez wladze uroczystościach związanych z miejscem zamieszkania respondentów [w \%]

\begin{tabular}{||l|c|c|c|c|c||}
\hline & Galicja & Kongresówka & Górny Śląsk & Wielkopolska & ZZiP \\
\hline Tak & 32,5 & 32,6 & 52,1 & 49,5 & 50,0 \\
\hline Nie & 67,5 & 67,4 & 47,9 & 50,5 & 50,0 \\
\hline Razem & 100,0 & 100,0 & 100,0 & 100,0 & 100,0 \\
\hline
\end{tabular}

Źródło: Opracowanie własne na podstawie wyników badań.

Dane zawarte w tabeli 5 pokazują, że więcej tego typu wydarzeń jest organizowanych na Górnym Śląsku w Wielkopolsce i na ziemiach zachodnich i północnych co mogłoby 
świadczyć o większej identyfikacji mieszkańców tych regionów z miejscowościami, w których oni mieszkają. W przypadku ziem zachodnich po roku 1989 proces definiowania ich tożsamości społeczno-kulturowej uległ przyspieszeniu i zapewne tego typu wydarzenia są jednym ze wskaźników tego przyspieszenia.

Uzasadnianie swojej deklaracji jako patrioty lokalnego często dla naszych respondentów było okazją do krytycznej oceny współczesności jeśli chodzi o pozycję regionów w III Rzeczpospolitej: „Region jest eksploatowany bezceremonialnie przez stolicę. Sprzeciw wobec tego zjawiska jest najważniejszym wyrazem. Kraj jest skrajnie scentralizowany, co się nie zmieniło od czasów PRL. Wyraża się to w odbieraniu mu podmiotowości i prawa decydowania o sobie. Koszty nieuniknionych przemian związanych z upadkiem systemu PRL są tak rozkładane by jak najmniej dotknęły stolicę i jej okolice, a ciężary oraz koszty zrzucane są na peryferia (bo tego «nie widać» z wieżowców stolicy). Towarzyszy temu przemoc ideologiczna jak za komuny - rugowanie innych niż Kongresówka tradycji i pamięci lokalnych, nachalny kult warszawskich rzekomych bohaterów. W stosunku stolicy do innych regionów widoczny jest polski nacjonalizm i ksenofobia połączone z jawnie wrogim stosunkiem do Niemiec i niemieckości oraz pozostałości niemieckiej kultury. 60 lat po wojnie to jest absurd i świadczy o świadomym lub podświadomym hołdowaniu endeckiej ideologii. Stolica czyni wszystko by zacierać ślady historycznej (czyli niemieckiej) przeszłości tych ziem (81/Śl.)".

Nasi respondenci deklarowali, że brali udział w ostatnich wyborach samorządowych (78\% deklaracji) i wówczas głosowali przede wszystkim na kandydata reprezentującego lokalny komitet wyborczy (46\% wszystkich badanych), a w drugiej kolejnością na kandydata startującego z list ogólnopolskich partii politycznych ( $26 \%$ ogółu badanych). Odpowiedzi na pytania o udział w wyborach wywołują najwięcej sceptycyzmu, jeśli chodzi o porównywalność wyników naszych badań z deklaracjami dotyczącymi postaw wobec Polaków w ogóle. O frekwencji w wyborach samorządowych na poziomie $78 \%$ w najbliższej perspektywie trudno realnie myśleć. Oczywiście pobieżna analiza odpowiedzi udzielonych w tych badaniach oraz wykształcenie respondentów uprawomocnia ocenę, że są nimi osoby ponadprzeciętnie związane z regionem, angażujące się $\mathrm{w}$ jego sprawy (społecznicy, działacze lokalni, dziennikarze, nauczyciele, pracownicy naukowi), a więc kategorie społeczne, które częściej uczestniczą w wyborach. Jednak różnica pomiędzy rzeczywiście głosującymi i deklaracjami składanymi przez naszych respondentów jest zbyt duża, aby mogła być faktyczna.

Ostatnim pytaniem kwestionariusza było pytanie, którego intencją było umożliwienie respondentom podzielenie się uwagami wprost dotyczącymi badania bądź refleksjami na marginesie problemu, którego dotyczyły badania. Niemal 20\% badanych skorzystało z tej okazji, co niewątpliwie świadczy o tym, że badania ich zainteresowały i wywołały refleksje wykraczające poza tematykę wprost związaną z badaniami. Obok uwag krytycznych dotyczących samego narzędzia badawczego, respondenci najczęściej dzielili się swoimi refleksjami na temat uwarunkowań determinujących współczesne postawy i zachowania Polaków również w obszarze, który był przedmiotem tego badania: „Sądzę, że nie trzeba przez całe życie znajdować się w jednym kraju/regionie/mieście, by uchodzić i uważać siebie za patriotę, czy też lokalnego patriotę. Wiele osób jest zmuszana do wyjazdu przez sytuację w kraju. Nie ma dla nich miejsc pracy lub są takie, które nie wychodzą naprzeciw ich możliwościom, wykształceniu czy oczekiwaniom finansowym. 
To, że zarabiają godziwe pieniądze za granicą nie oznacza, że nie są do Polski przywiązani. Kiedy wypracują sobie zagraniczne emerytury, to zapewne wrócą do ojczyzny, by wieść bezstresowe życie wśród rodaków. Patriotyzmem nie jest trwanie w beznadziejnych często realiach, ale wśród najbliższych czy w ukochanym mieście. Trudno dziś rozmawiać o patriotyzmie... wielu go traci właśnie przez opisane powyżej kwestie czysto bytowe. Nie utożsamiają się z ojczyzną, gdyż nie daje im ona nic w zamian. Żyjemy w czasach pokoju, gdy mało prawdopodobny jest konflikt zbrojny na miarę wojny światowej. Tym samym nie ma powodu, by przelewali swoją «krew» za «miłość, honor i ojczyznę» (578/Wlkp)".

\section{Uwagi końcowe}

Analiza zebranego materiału empirycznego pokazuje, że dyskusja na temat patriotyzmu nadal wywołuje żywą dyskusję. Podziały nie przebiegają wg tradycyjnych linii młodzi-starzy, regiony tradycyjne, regiony ,nowe”, zwolennicy takiej czy innej partii politycznej, osoby deklarujące poglądy konserwatywne, liberalne czy lewicowe, wykształceni mniej wykształceni. Najważniejszym kryterium dzielącym uczestników naszych badań jest sytuacja społeczna, subiektywna ocena sytuacji życiowej, miejsce na rynku pracy.

Na postrzeganie patriotyzmu również mocno wpływa fakt, że od 10 lat Rzeczpospolita Polska jest krajem członkowskim Unii Europejskiej, co w konsekwencji doprowadziło do tego, że około 2 milionów Polaków, mniej lub bardziej na trwałe, opuściło kraj nie zrywając z nim więzi. Podczas przyjazdów, często ze znajomymi z kraju migracji, wstępując w związki małżeńskie z cudzoziemcami, weryfikują swoje wyobrażenie patriotyzmu ukształtowane przez szkołę, rodzinę, kościół media podczas pobytu w Polsce. Najczęściej jest to odejście od patriotyzmu martyrologicznego, bogoojczyźnianego często ksenofobicznego w kierunku patriotyzmu kosmopolitycznego, którego istotą jest akceptacja dla innych grup narodowych i akceptacja innych zachowań i postaw społecznych i kulturowych. Odejście od patriotyzmu przeciwko komuś na rzecz patriotyzmu na rzecz czegoś i co najważniejsze patriotyzmu zakładającego przekroczenie myślenia w kategoriach ponadnarodowych na rzecz patriotyzmu europejskiego rozumianego jako bycie dumnym z faktu, że jestem Europejczykiem. Jest to w pewnym sensie nawiązanie do słów Jana Józefa Lipskiego sformułowanych w 1981, kiedy to postuluje on abyśmy kształtowali postawy, które nie pozwolą utracić szansy abyśmy razem z naszymi sąsiadami na powrót stali się częścią wspólnoty europejskiej: ,[...] podbijając bębenka «dumy narodowej» i manipulując fobiami; stracimy wszelkie szanse, nawet jeśli się one otworzą, współdziałania z innymi, jak my uciskanymi przez sowietyzm narodami - tymczasem nie wolno nam czekać na szczęśliwe zbiegi okoliczności, musimy zacząc pracować nad zbudowaniem solidarności uciskanych; zamkniemy w rezultacie sobie drogę do Zachodniej Europy, w której widzimy swoją kolebkę kulturową - na zawsze [...]" (Lipski, 1996, s. 73).

Zmiana prowadzi również do tego, że patriotyzm postrzegany jest jako kompleks cech i zachowań, które powinny być użyteczne tu i teraz zarówno w wymiarze ogólnym, jak i w wymiarze regionalnym. Współczesny patriotyzm, podobnie jak życie społeczne 
w ogóle, jest bardziej egoistyczny w stosunku do patriotyzmu z okresu, gdy zagrożony był byt państwowy i narodowy, jak również z okresu, w którym zarówno przez Kościół katolicki, jak i państwo komunistyczne integrowani byliśmy na poziomie wspólnoty narodowej z różnymi, często przeciwstawnymi, odwołaniami i celami. Polacy są po prostu patriotami, gdy jest to użyteczne, bądź gdy im się to w wymiarze jednostkowym czy najwyżej rodzinnym „opłaca”. Nadal najbardziej upośledzone, w kontekście tematu badań, są regiony Polski nazywane nadal przez część badaczy ziemiami zachodnimi i północnymi. Wynika to $\mathrm{z}$ faktu, że proces definiowania ich tożsamości regionalnej rozpoczął się relatywnie późno, bo dopiero po 1989 roku, mimo że w granicach państwa polskiego znalazły się już w 1945. Państwo komunistyczne integrowało mieszkańców tych regionów ze wspólnotą państwową pomijając poziom regionalny i w opozycji do zastanego dziedzictwa kulturowego, które najczęściej było niemieckie, a więc z definicji wrogie czy zafałszowane przez naukę niemiecką. Dopiero odejście pokolenia doświadczonego wielowymiarową konfrontacją polsko-niemiecką na tych ziemiach pozwoliło sięgnać ich obecnym mieszkańcom do tego źródła, przy definiowaniu swojej tożsamości regionalnej.

Jednak najważniejszy wniosek, jaki można sformułować na podstawie analizy zebranych danych jest taki, że nie potwierdzały się oczekiwania dotyczące jakiejś wyraźnej różnicy w postrzeganiu patriotyzmu lokalnego w opozycji do patriotyzmu wynikającego z bycia członkiem wspólnoty narodowej. Patriotyzm lokalny dla badanych jest elementem patriotyzmu narodowego, nie są to dla nich patriotyzmy wykluczające się. Wyjątkiem wydaje się być sytuacja na Górnym Śląsku, gdzie patriotyzm lokalny dla części respondentów definiowany jest w opozycji do patriotyzmu narodowego. Życzeniem autorów badań jest to, aby wnioski z nich inspirowały dyskusję na temat patriotyzmu przed obchodami kolejnych rocznic uchwalenia w dniu 3 Maja 1791 roku przez Sejm Rzeczpospolitej Obojga Narodów konstytucji.

\section{Bibliografia}

Berger P., Luckmann T. (1983), Społeczne tworzenie rzeczywistości, Państwowy Instytut Wydawniczy, Warszawa.

Czy jesteśmy dumni ze swojej polskości (1994), BS/164/146/94, Centrum Badania Opinii Społecznej, Warszawa.

Lipski J. J. (1996), Powiedzieć sobie wszystko. Eseje i sqsiedztwie polsko-niemieckim, Wydawnictwo Polsko-Niemieckie, Warszawa.

Małe ojczyzny - poczucie przynależności Polaków (2009), BS/151/2009, Centrum Badania Opinii Społecznej, Warszawa.

Ossowski St. (1984), O ojczyźnie i narodzie, Państwowe Wydawnictwo Naukowe, Warszawa.

Raciborski J. (1997), Polskie wybory. Zachowania wyborcze społeczeństwa polskiego w latach 1989-1995, Wydawnictwo „Scholar”, Warszawa.

Rozumienie patriotyzmu (2008), BS/167/2008, Centrum Badania Opinii Społecznej, Warszawa. 


\title{
Contemporary Polish patriotism: between the community and national regional community
}

\begin{abstract}
Summary
The 25th anniversary of the recovery of political sovereignty by Poland as a result of the collapse of communism in Europe passed in 2014. On this occasion, a whole series of studies, analyses, research was carried out which was aimed at seeking answers to the question of how the Polish public evaluates the passing of a quarter-century. The presented text is the result of research which is a part of this anniversary trend, the modern understanding of patriotism in general as well as regional patriotism. The research was conducted by the author in the autumn of 2013. The empirical material was collected through the Internet, which strongly placed the issue of representativeness of the results, however, due to the number of statements it can be the basis to formulate general conclusions about what is contemporary patriotism for the Poles. General conclusions are that patriotism also became practical, that is, the Poles are patriots when this is useful. Yet what other conclusion can be drawn is that the majority of respondents is a component of regional pride of patriotism in general. The exception is Upper Silesia, where local patriotism is next to national patriotism and the opposition it is often the latter. Yet another conclusion to be drawn in the light of the results obtained is that patriotism is changing its face in the martyrdom of patriotism actions and their effects according to the "principle of the deeds you shall know them."
\end{abstract}

Key words: patriotism, regional pride, regionalism, identity 